\title{
Fattiviracins, Antiviral Antibiotics Produced by an Actinomycete
}

\author{
Masaru Uyeda* \\ Department of Pharmaceutical Microbiology, Faculty of Medical \& Pharmaceutical Sciences, \\ Kumamoto University, Kumamoto 862-0973, JAPAN
}

(Received Oct. 17, 2003)

\begin{abstract}
In 1995, we discovered new antiherpetic antibiotics, called fattiviracins. The producing organism was classified as a strain belonging to Streptomyces microflavus. The strain produced at least 13 fattiviracin derivatives (FV-1 to FV-13). Fattiviracins were obtained as a white amorphous powder, and their molecular weights are in the range of 1400 to 1500 . They are readily soluble in water, methanol, pyridine and DMSO, but insoluble in other organic solvents. Fattiviracins have macrocyclic diesters formed by the binding of two trihydroxy fatty acids and two D-glucose residues in the molecule, and they can be divided into 5 families, according to the length of fatty acid moiety.

Fattiviracins have a potent activity against enveloped DNA viruses such as the herpes family, HSV-1 and VZV and enveloped RNA viruses such as influenza A and B viruses, and three strains of HIV-1, in the order of a few $\mu \mathrm{g} / \mathrm{ml}$ of $\mathrm{EC}_{50}$. The biosynthetic pathway of fattiviracins is also becoming clearer. Using bacitracin-resistant strains, enhanced and astringent production of fattiviracin was recognized: fattiviracin FV-13, having the longest fatty acid chains in the molecule was dramatically enhanced by a $\mathrm{C}_{55^{-}}$ isoprenyl phosphate metabolism.
\end{abstract}

\section{INTRODUCTION}

Most of the successes in the development of antivirals active against herpes viruses have been achieved with synthetic nucleoside analogues. It is well known that a synthetic chemotherapeutic agent, acyclovir, studied by Elion et al. ${ }^{1,2)}$, (awarded the Nobel Prize in the field of Physiology or Medicine, 1988), is the best medicine for herpes virus infections. Acyclovir has virus-specific activation in virus-infected cells and its activated form inhibits viral DNA replication through obligate chain termination. The remarkable characteristic of acyclovir is its lack of effect on uninfected cells. This lack of cytotoxicity has subsequently translated into an outstanding safety profile in the clinic. Over the past 20 years acyclovir has become the drug of choice for the treatment and suppression of herpes infections.

Why could microorganisms including actinomycetes not produce the valuable antiviral antibiotics? Recently, new antiviral agents produced by actinomycetes, which are effective for herpes virus or human immunodeficiency virus, have been found: cycloviracins $B_{1}$ and $B_{2}$, and fattiviracins having the macrocyclic dilactones formed by the binding of two trihydroxy fatty acids and two D-glucose residues in the molecules.

The author will introduce the antiviral antibiotics, mainly fattiviracins, that were isolated and studied in our laboratories.

\section{Cycloviracins ${ }^{3-5)}$}

The cycloviracin-producing strain, Kibdelosporangium albatum No. R761-7 (ATCC 55061), was isolated from a soil sample collected in Mindanao Island, the Philippines. A complex of new antibiotics was extracted from the fermentation broth with 1-butanol, and purified by column chromatographies on silica gel, reversed phase $\mathrm{C}_{18}$, preparative HPLC and Sephadex LH-20. Two major components, cycloviracins $\mathrm{B}_{1}$ and $\mathrm{B}_{2}$, have been isolated from the complex. They were soluble in methanol, pyridine and dimethyl sulfoxide, slightly soluble in ethyl acetate and acetone, but practically insoluble in $n$-hexane, chloroform and water. Their structures have been determined by chemical and spectroscopic methods including 2D NMR correlation spectroscopy. The antibiotics are unique macrocyclic diesters consisting of two D-glucoses, three 2- $O$-methyl-D-glucoses and two $\left(\mathrm{C}_{24}\right.$ and $\left.\mathrm{C}_{26}\right)$ hydroxy fatty acids (Fig. 1).

Antiviral activity of cycloviracins $\mathrm{B}_{1}$ and $\mathrm{B}_{2}$ was evaluated by the dye uptake ${ }^{6}$ and the plaque reduction assay ${ }^{7)}$ using herpes simplex virus type 1 (HSV-1) (KOS strain) infection in Vero cells (a cell line of kidney from African green monkey). In the dye uptake assay, $200 \mu \mathrm{l}$ of the Vero cell suspension containing $1.6 \times 10^{4}$ cells was poured into each well of 96-well microplates, and then $50 \mu \mathrm{l}$ of a medium containing a test compound at various concentrations was added to each well. The viral suspension $(50 \mu \mathrm{l})$ containing approximately $30 \times \mathrm{TCID}_{50}$ was inoculated at 37 ${ }^{\circ} \mathrm{C}$ for $72 \mathrm{hr}$ under a $5 \% \mathrm{CO}_{2}$ in humidified air environ-

*Corresponding author: Phone: +81-96-371-4323. Fax: +81-96-371-4323. E-mail: uyeda@gpo.kumamoto-u.ac.jp 


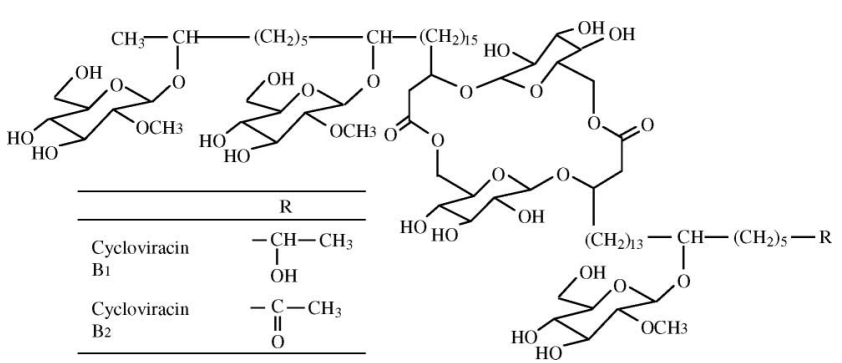

Fig. 1. Structures of cycloviracins $\mathrm{B}_{1}$ and $\mathrm{B}_{2}$.

ment, and the degree of inhibition of the virus-induced cytopathic effect and the drug-induced cytotoxicity were determined by means of the uptake of neutral red. $\mathrm{ID}_{50}$ was expressed as the concentration showing the 50\% inhibition of the cytopathic effect of control, and $\mathrm{TD}_{50}$ was the concentration exhibiting the $50 \%$ cytotoxicity against Vero cells without viral infection. The antiviral activity of cycloviracins $\mathrm{B}_{1}$ and $\mathrm{B}_{2}$ was also evaluated by the conventional plaque reduction assay using a 24-well microplate. Cycloviracins $\mathrm{B}_{1}$ and $\mathrm{B}_{2}$ demonstrated a potent antiviral activity against $\mathrm{HSV}-1$ with $\mathrm{ID}_{50}$ values of 4.9 and 5.0 $\mu \mathrm{g} / \mathrm{ml}$, respectively by the dye uptake assay. In the plaque reduction assay, cycloviracins $\mathrm{B}_{1}$ and $\mathrm{B}_{2}$ showed somewhat weaker antiviral activity than that in the dye uptake assay, $\mathrm{ID}_{50}$ values being 10.9 and $9.3 \mu \mathrm{g} / \mathrm{ml}$, respectively. They showed no cytotoxicity against Vero cells up to 400 $\mu \mathrm{g} / \mathrm{ml}$. The antimicrobial spectra of cycloviracins $B_{1}$ and $\mathrm{B}_{2}$ against various bacteria and fungi were also examined. Cycloviracins $\mathrm{B}_{1}$ and $\mathrm{B}_{2}$ exhibited weak antibacterial activity against aerobic Gram-positive bacteria, especially for Staphylococcus aureus, Staphylococcus epidermidis or Bacillus subtilis, but did not show the activity against Gram-negative bacteria and fungi.

\section{Fattiviracins}

HSV-1 causes a wide spectrum of acute and recurrent diseases in humans. Although acyclovir (ACV), an excellent synthetic antiherpetic agent, is now in clinical use for the treatment of herpes diseases, the appearance of ACVresistant mutants is thought to be a serious problem.

In order to search for novel antiherpetic agents in place of ACV, we have screened antiherpetic agents produced by soil microorganisms, especially actinomycetes strains, using a rapid method for detection of antiherpetic agents using 96-well microtiter plates by plaque reduction assay ${ }^{7}$. Of the approximately 2,500 actinomycetes strains tested, four new antiherpetic agents were found in our laboratories: AH-135Y (Fig. 2) (a new glutarimide antibiotic) produced by Streptomyces albovinaceus strain No. 1358), AH758 (Fig. 3) (a new macrolide antibiotic belonging to bafilomycin ${ }^{9)}$ ) produced by Streptomyces rochei strain No. 758 ${ }^{10}$ ) AH-1763IIa (Fig. 4) (a new antibiotic belonging to the pluramycin group ${ }^{11)}$ ) produced by Streptomyces cyaneus strain No. $1763^{12)}$ and fattiviracins (new antibiotics belonging to sugar-fatty acid lactone) produced by

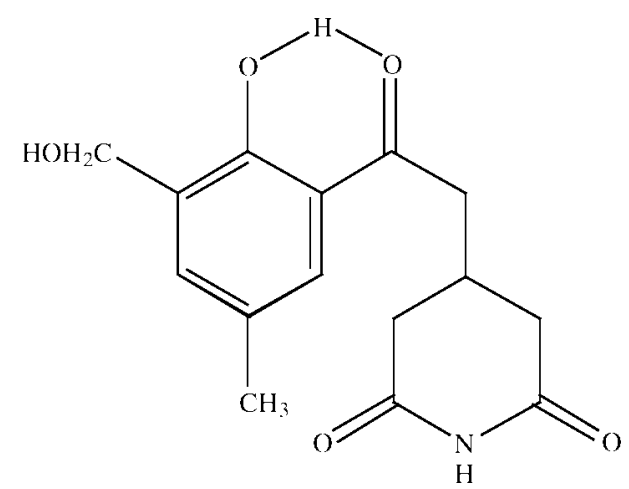

Fig. 2. Structure of AH-135Y.

Streptomyces microflavus strain No. 2445 $5^{13-17)}$.

AH-135Y showed an antiherpetic activity of $2.1 \mu \mathrm{g} / \mathrm{ml}$ as $\mathrm{EC}_{50}$ against $\mathrm{HSV}-1$, and cytotoxicity of $30.0 \mu \mathrm{g} / \mathrm{ml}$ as $\mathrm{IC}_{50}$ against Vero cells, and therefore the selective index (ratio of $\mathrm{IC}_{50}$ to $\mathrm{EC}_{50}$ ) was estimated as 14.3 . AH-135Y was also effective on influenza $A$ virus and respiratory syncytial virus (RS virus).

AH-758 showed an antiherpetic activity of $0.09 \mu \mathrm{g} / \mathrm{ml}$ as $\mathrm{EC}_{50}$ against $\mathrm{HSV}-1$, and cytotoxicity of $1.3 \mu \mathrm{g} / \mathrm{ml}$ as $\mathrm{IC}_{50}$ against Vero cells and therefore the selective index was estimated as 14.4. The $\mathrm{EC}_{50}$ against cytomegalovirus was less than $0.5 \mathrm{ng} / \mathrm{ml}$, so AH-758 shows promise as an agent to fight cytomegalovirus infection.

AH-1763 IIa showed an antiherpetic activity of 2.1 $\mu \mathrm{g} / \mathrm{ml}$ as $\mathrm{EC}_{50}$ against HSV-1, and cytotoxicity of 15.2 $\mu \mathrm{g} / \mathrm{ml}$ as $\mathrm{IC}_{50}$ against Vero cells and therefore the selective index was estimated as 7.2.

Thirteen additional compounds were purified, but they were found to be known antibiotics.

\section{Isolation and Purification of Fattiviracins ${ }^{13,15)}$}

In 1995, we discovered new antiherpetic agents, called fattiviracins. The producing strain No. 2445 was isolated from a soil sample collected at a riverside of River Tuboi in Kumamoto, Japan. The characterization and identification of this strain were carried out mainly according to Bergey's Manual of Systematic Bacteriology ${ }^{18)}$ and the International Streptomyces Project (ISP) report ${ }^{19}$ ). From its cultural and taxonomic characteristics, this strain was classified as a strain belonging to Streptomyces microflavus. Therefore, it is called Streptomyces microflavus strain No. 2445 hereafter. The culture has been deposited to the National Institute of Bioscience and Human-Technology in the Agency of Industrial Science and Technology under the accession No. FERM P-16524.

Fermentation was carried out at $28{ }^{\circ} \mathrm{C}$ for $96 \mathrm{~h}$, and the filtrate was used to isolate fattiviracins. This strain turned out to produce at least 13 fattiviracin derivatives (FV-1 to FV-13). Fattiviracins were purified through column chromatographies on Diaion HP-10, silica gel, ODS and preparative HPLC using a reverse phase column. All the 
<smiles>COC(=CC(C)=CC(C)C(O)C(C)C)C(=O)OC(C(C=CC=C(C)CC(C)C)OC)C(C)C(O)C(C)C1(Cl)CC(OC(=O)C=CC(=O)OCC2=CCC(=O)N2)C(C)C(C(C)C)O1</smiles>

Fig. 3. Structure of AH-758.<smiles>Cc1cc2c(c3oc(C(C)C(C)O)cc(=O)c13)C(=O)c1c(O)cccc1C2=O</smiles>

Fig. 4. Structure of AH-1763IIa.

purification steps were monitored by measuring the inhibitory activity of plaque formation by HSV-1. Fattiviracins were obtained as a white amorphous powder. Its crystallization trial is now carried out for X-ray analysis of the structure. They were readily soluble in water, methanol, pyridine and dimethyl sulfoxide, but insoluble in $n$-hexane, chloroform, ethyl acetate and acetone. The structures of fattiviracins were determined by several spectroscopic analyses and chemical degradations. Ten derivatives, except fattiviracins FV-1 to FV-3, belonged to sugar-fatty acid lactone. Fattiviracins FV-1 to FV-3 remain undetermined because only trace amounts were available. As shown in Fig. 5, fattiviracins have macrocyclic diesters formed by the binding of two trihydroxy fatty acids and two D-glucose residues in the molecules, and they can be divided into 5 families according to the length of fatty acid moiety. Some of them will be stereoisomer to each other. They are closely related to cycloviracins $B_{1}$ and $B_{2}$, but differ from these known compounds in both the length of their side chain and the sugar moiety. Cycloviracins have three 2-O-methyl-D-glucoses bound to two hydroxy fatty acids as described above. On the other hand, fattiviracins have two normal glucoses bound to the same acids. Fattiviracins show almost the same antiviral activity against HSV-1 $\left(\mathrm{EC}_{50}=2.5-3.1 \mu \mathrm{g} / \mathrm{ml}\right)$ regardless of the length of their fatty acid chains.

\section{Antiviral Spectra ${ }^{16)}$}

Antiviral spectra against various viruses were examined with fattiviracin FV-8 (Table 1). The antiviral activities of FV-8 on HSV-1, VZV, influenza and polio viruses were measured by a plaque reduction assay. Briefly, confluent monolayers of Vero or MDCK (canine kidney) cells in 6well plates were infected with $100 \mathrm{PFU}$ (plaque-forming unit) of each virus. After a 1-hr adsorption period, the cultures were overlaid with Dulbecco's modified Eagle's minimum essential medium (DMEM) containing 2\% heatinactivated fetal calf serum (FCS) (Gibco BRL), including various concentrations of FV-8. The plates were incubated in a $\mathrm{CO}_{2}$ incubator for 3 days, then fixed with formalin and stained with crystal violet in methanol. Infectious virus production was measured by counting plaques caused by virus-induced cytopathic effects. The toxicities to the host cells were examined by means of the uptake of crystal violet ${ }^{20)}$.

The antiviral activity of FV-8 on HIV-1 was tested by MAGI (multinuclear activation of a galactosidase indicator) assay ${ }^{21)}$. MAGI/CCR5 cells $\left(3 \times 10^{5}\right.$ cells $)$ were infected with three types of HIV-1 (IIIB/T-, JR-FL/M-, or 89.6/dual-tropic strains) and incubated for 2 days in a growth medium (10\% FCS + RPMI 1640) containing different concentrations of FV-8. Individual infected cells were counted in situ with a light microscope by virtue of their blue color after incubation with 5-bromo-4-chloro-3indolyl- $\beta$-D-galactopyranoside (X-Gal).

FV-8 had a similar antiviral activity against IIIB, JR-FL, and 89.6 strains of HIV-1 regardless of the cell tropism of HIV-1, and these $\mathrm{EC}_{50}{ }^{\prime}$ s were $4.3,3.5$, and $6.1 \mu \mathrm{g} / \mathrm{ml}$, respectively. The antiviral activities of FV-8 had antiviral $\mathrm{EC}_{50}$ 's of $2.7,3.0,1.9$, and $3.3 \mu \mathrm{g} / \mathrm{ml}$ against HSV-1, $\mathrm{VZV}$, influenza A virus and influenza B virus, respectively. FV-8 has a potent activity against enveloped DNA viruses of the herpes family, HSV-1 and VZV, and enveloped RNA viruses of influenza A virus, influenza B 


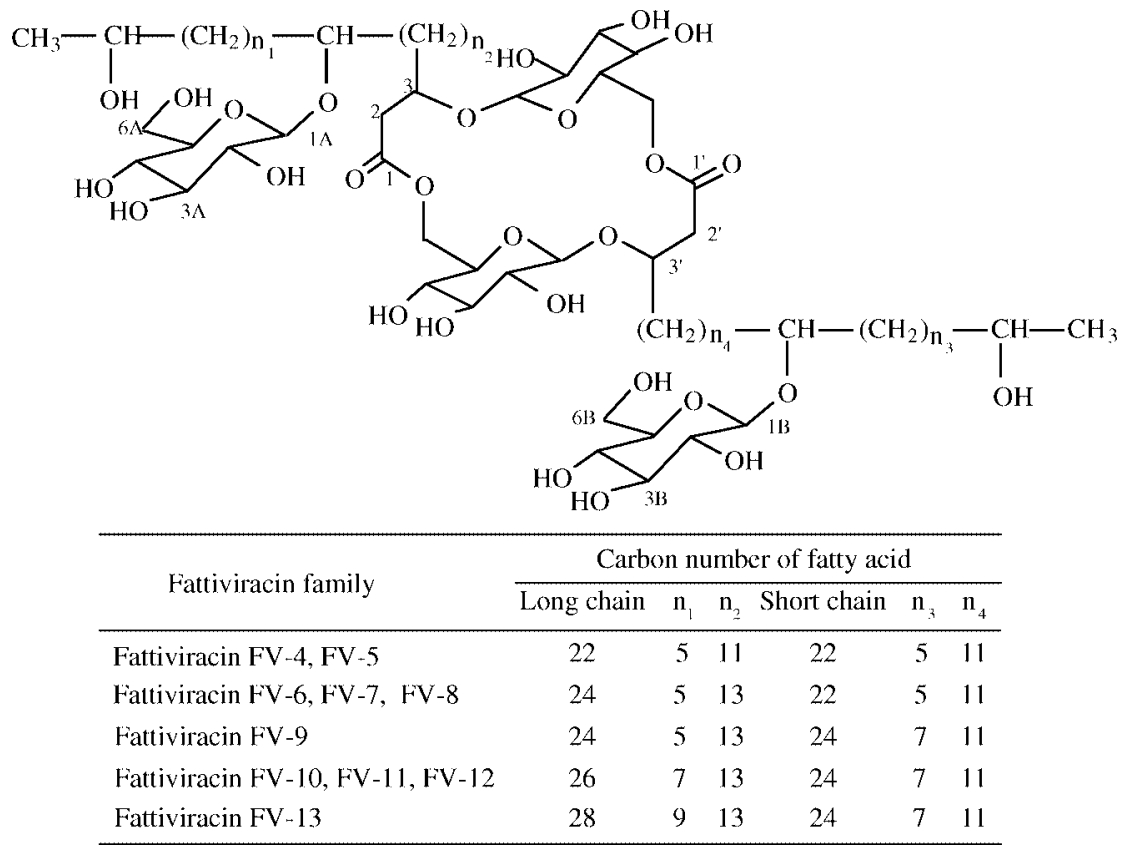

Fig. 5. Structures of fattiviracins.

Table 1. Antiviral activities and cytotoxicities of fattiviracin FV-8.

\begin{tabular}{lllcr}
\hline Virus & Strain & Cell & $\begin{array}{c}\text { Antiviral activity } \\
\left(\mathrm{EC}_{50}, \mu \mathrm{g} / \mathrm{ml}\right)\end{array}$ & $\begin{array}{c}\text { Cytotoxicity } \\
\left(\mathrm{IC}_{50}, \mu \mathrm{g} / \mathrm{ml}\right)\end{array}$ \\
\hline HIV-1 & IIIIB $^{\mathrm{a}}$ & MAGI/CCR5 & 4.3 & 280 \\
HIV-1 & JR-FL $^{\mathrm{b}}$ & MAGI/CCR5 & 3.5 & 280 \\
HIV-1 & $89.6^{\mathrm{c}}$ & MAGI/CCR5 & 6.1 & 280 \\
HIV-1 & KOS & Vero & 3.0 & $>$ \\
VZV & Oka & Vero & 1.9 & - \\
Infiuenza A & H1N1 & MDCK & 3.3 & - \\
Infiuenza B & B/Lee/40 & MDCK & $>1000$ & $>$ \\
Polio & Sabin type 1 & Vero & \\
\hline
\end{tabular}

a: T tropic virus strain. b: M-tropic virus strain. c: Dual tropic virus strain.

$\mathrm{d}$ : a clone of MAGI cells that express the human chemokine receptor CCR5. MAGI cell line is a HeLa cell clone expressing human CD4 and HIV LTR- $\beta$-galactosidase.

virus, and three strains of HIV-1. However, it showed no antiviral activity against the unenveloped RNA virus of the polio virus, even at the concentration of $1 \mathrm{mg} / \mathrm{ml}$. It has no cytotoxicity against Vero cells even at a concentration of 5 $\mathrm{mg} / \mathrm{ml}$. Therefore the selective index of FV-8 against HSV-1 was estimated as over 1852, which exhibits excellent selectivity compared to the selective index 850 of the antiherpetic agent, ACV. In addition, the low toxicity is expected to be very potent for the application.

\section{Mechanism of antiviral action ${ }^{16}$}

The effects of FV-8 treatment time on HIV-1 infection were examined, and are shown in Fig. 6. In the addition just before viral infection, FV-8 showed strong antiviral activity $\left(\mathrm{EC}_{50}=4.3 \mu \mathrm{g} / \mathrm{ml}\right)$, but $1 \mathrm{hr}$ later, the activity decreased $\left(\mathrm{EC}_{50}=28.9 \mu \mathrm{g} / \mathrm{ml}\right)$, and no antiviral activity was observed in the addition $3 \mathrm{hr}$ after HIV-1 infection $\left(\mathrm{EC}_{50}\right.$ $>100 \mu \mathrm{g} / \mathrm{ml}$ ). These results suggested that FV-8 does not show antiviral activity against the HIV-1 that has already invaded host cells, that is, the agent acts on HIV-1 particles directly before infection.

To examine the effects of FV-8 on HIV-1 particles, IIIB strain was treated with different concentrations of FV-8 for $30 \mathrm{~min}$ at $37^{\circ} \mathrm{C}$. After ultracentrifugation $(60,000 \mathrm{rpm}, 60$ $\mathrm{min}$ ), the precipitate (viral fraction) was suspended in a growth medium and infected to MAGI/CCR5 cells. The lysis of the viral envelope and capsid of HIV-1 particles was estimated on the basis of the amount of p24 in the viral fraction measured by HIV-1 p24 capsid enzymelinked immunosorbent assay (Abbott) ${ }^{22}$.

The effects of FV-8 on HIV-1 particles are shown in Fig. 7. Although the antiviral activity of FV-8 increased with the concentration, the amount of capsid protein p24 of HIV-1 was constant. Therefore, FV-8 inactivates HIV-1 particles without lysis of the viral particles, and it inhibits 


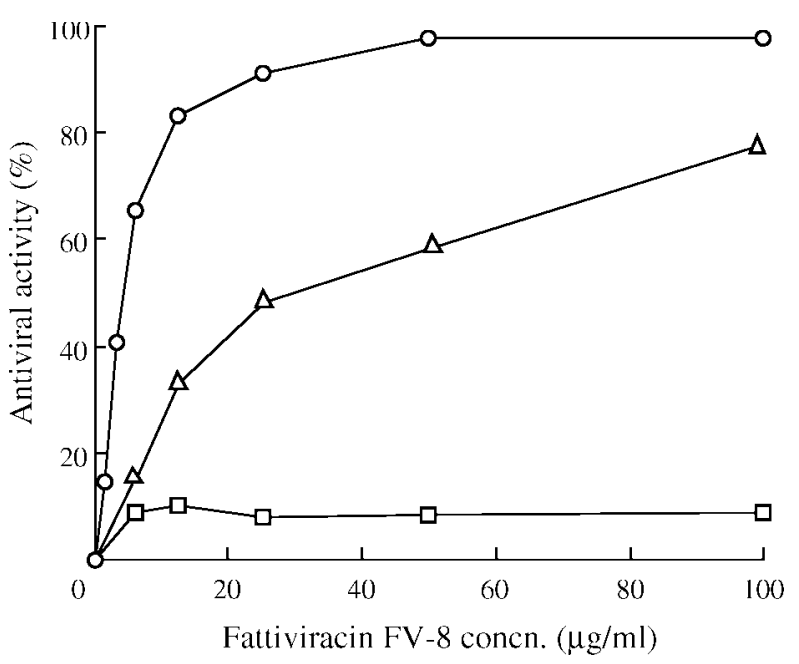

Fig. 6. Effect of treatment time on HIV-1 infection. $\bigcirc$, Addition of FV-8 just before HIV-1 infection. $\triangle$, Addition of FV-8 at $1 \mathrm{~h}$ after HIV-1 infection. $\square$, Addition of FV-8 at $3 \mathrm{~h}$ after HIV-1 infection.

viral entry into the host cells. The antiviral mechanism of FV-8 is clearly different from those of zidovudine ${ }^{23)}$ and ritonavir ${ }^{24)}$, the antiviral activities of which are inhibitions of reverse transcriptase and protease in the HIV-1 particles, respectively.

In recent studies, it was found that FV-8 did not interact with gp120 binding with CD4 on the surface of a host cell, but did interact with trans-membrane gp41 connecting with the gp120.

\section{Biosynthesis of fattiviracin ${ }^{17)}$}

Fattiviracins have four glucoses in the molecule. To examine the incorporation of glucose into the FV-8 molecule, $\left[1-{ }^{13} \mathrm{C}\right] \mathrm{D}$-glucose was fed into the culture medium. Labeled FV-8 was isolated and its ${ }^{13} \mathrm{C}$ NMR spectrum was

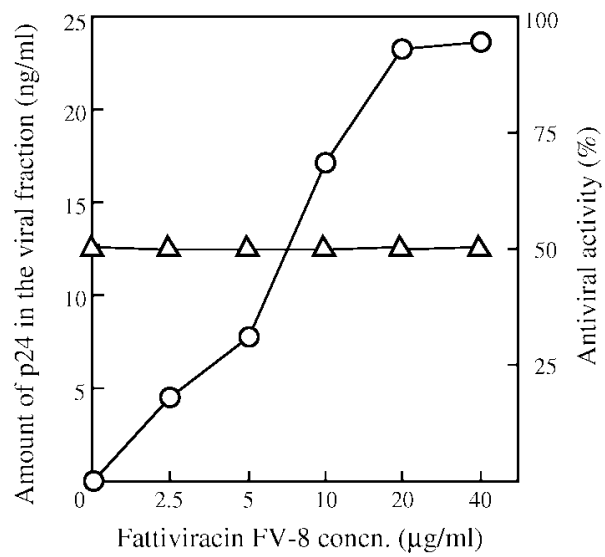

Fig. 7. Effects of fattiviracin FV-8 on HIV-1 particles. $\bigcirc$, Antiviral activity of FV-8. $\triangle$, Amount of p24 in the viral fraction. examined to identify the carbon enrichment. As shown in Table $2,{ }^{13} \mathrm{C}$ incorporation was observed at each of the carbon numbers $25,23^{\prime}, 1 \mathrm{~A}$ and $1 \mathrm{~B}$, which correspond to the 1-carbon of four glucose residues in the FV-8 molecule. The results suggest that the strain has the ability to directly incorporate glucose in the culture medium into the FV-8 molecule.

For the production of the modified FV-8's consisting of various sugar residues, several types of sugar, such as galactose, mannose, fructose, xylose, and arabinose were used in place of glucose in the medium No. 4 consisting of glucose $5.0 \%$, corn steep liquor $1.0 \%$, peptone $0.5 \%, \mathrm{NaCl}$ $0.3 \%, \mathrm{CaCO}_{3} 0.3 \%$ (pH 7.0). Then, each modified FV-8 was purified from respective culture filtrates and degraded with $\mathrm{HCl}$ to identify the sugar residues. The antiherpetic activity and sugar residues of each modified FV-8 were examined and are summarized in Table 3. The modified FV-8's showed almost the same antiherpetic activity, and the sugar residues in these molecules were all found to be glucoses. Also, the structures of the modified FV-8's were identified as an original FV-8 from the NMR and mass spectral data. In addition, there were no modified fattiviracins with sugars other than glucose in fattiviracin derivatives produced by the strain. These results suggest that the strain may have the ability to convert different types of sugar in the culture medium to glucose which is exclusively incorporated into the FV-8 molecule.

The conversion of pentose (xylose) to hexose (glucose) is especially interesting. To confirm this conversion, an experiment using a resting-cell system was carried out, and the result of HPLC is shown in Fig. 8. A peak of xylose decreased by incubation with the resting-cell. After a 4

Table 2. ${ }^{13} \mathrm{C}$ Abundances in sugar moiety of fattiviracin FV-8 obtained from feeding experiments with ${ }^{13} \mathrm{C}$-labeled sugars.

\begin{tabular}{cccc}
\hline \multirow{2}{*}{ Carbon } & $\delta \mathrm{c}$ & \multicolumn{2}{c}{ Relative abundance ${ }^{\mathrm{a}}$} \\
\cline { 3 - 4 } position & ppm & {$\left[1{ }^{13} \mathrm{C}\right]$ D-glucose } & {$\left[1-{ }^{13} \mathrm{C}\right]$ D-xylose } \\
\hline $25,23^{\prime}$ & 104.4 & $2.2^{*}$ & $2.3^{*}$ \\
& 104.5 & $2.3^{*}$ & $2.3^{*}$ \\
$26,24^{\prime}$ & 75.3 & 0.4 & 0.3 \\
$27,25^{\prime}$ & 78.1 & 0.6 & $1.4^{*}$ \\
$28,26^{\prime}$ & 71.6 & 0.4 & 0.7 \\
$29,27^{\prime}$ & 71.8 & 0.4 & 0.5 \\
$30,28^{\prime}$ & 65.2 & 0.8 & 0.9 \\
$1 \mathrm{~A}, 1 \mathrm{~B}^{\prime}$ & 103.7 & $2.5^{*}$ & $2.6^{*}$ \\
& 103.5 & $2.1^{*}$ & $2.0^{*}$ \\
$2 \mathrm{~A}, 2 \mathrm{~B}^{\prime}$ & 75.2 & 0.4 & 0.5 \\
& 75.1 & 0.4 & 0.5 \\
$3 \mathrm{~A}, 3 \mathrm{~B}^{\prime}$ & 78.1 & 0.5 & $2.7^{*}$ \\
$4 \mathrm{~A}, 4 \mathrm{~B}^{\prime}$ & 71.9 & 0.4 & 0.7 \\
$5 \mathrm{~A}, 5 \mathrm{~B}^{\prime}$ & 77.7 & 0.3 & 0.5 \\
$6 \mathrm{~A}, 6 \mathrm{~B}^{\prime}$ & 62.9 & 0.7 & 0.9 \\
& 62.8 & 0.6 & 0.7 \\
\hline
\end{tabular}

aPeak height ratio of ${ }^{13} \mathrm{C}$-enriched $\mathrm{FV}-8$ to unalabeled $\mathrm{FV}-8$.

*High level enrichment was observed. 
days incubation, a peak of glucose was detected in place of xylose. Moreover, the conversion of xylose to xylulose was verified by a cell-free extract system, as shown in Fig. 9. After incubation for $30 \mathrm{~min}$, the conversion rate of xylose to xylulose was $5 \%$, and the conversion increased with incubation time, and after $240 \mathrm{~min}$, the rate was $21.5 \%$. Further experimentation for the conversion of xylose to glucose was done by the $\left[1-{ }^{13} \mathrm{C}\right] \mathrm{D}$-xylose feeding experiment. As shown in Table $4,{ }^{13} \mathrm{C}$ incorporation was observed at each of the carbon numbers $25,27,23^{\prime}$, $25^{\prime}, 1 \mathrm{~A}, 3 \mathrm{~A}, 1 \mathrm{~B}$ and $3 \mathrm{~B}$, which correspond to the 1, 3-carbon of four glucose residues in the FV-8 molecule. These results may be explained by the conversion of xylose to glucose through the pentose phosphate pathway ${ }^{25)}$, as shown in Fig. 10. It is clear that the glucose converted from xylose is incorporated into the FV-8 molecule.

The biosynthesis of the non-sugar moiety of FV-8 was examined by feeding experiments using $\left[1-{ }^{13} \mathrm{C}\right]$ acetate and $\left[2-{ }^{13} \mathrm{C}\right]$ acetate. As shown in Table 5, the ${ }^{13} \mathrm{C}$ NMR spectrum of labeled FV-8 indicated that the carbon atoms of the non-sugar moiety in the FV-8 molecule are derived from acetic acid, according to an expected polyketide pathway ${ }^{26)}$.

Table 3. Antiherpetic activity and sugar residue in the modified $\mathrm{FV}-8$ produced in the medium containing various sugars.

\begin{tabular}{lcc}
\hline $\begin{array}{c}\text { Sugar added } \\
\text { to medium }\end{array}$ & $\begin{array}{c}\text { Sugar residue in } \\
\text { FV-8 molecule }\end{array}$ & $\begin{array}{c}\text { Antiherpetic activity } \\
\left(\mathrm{EC}_{50}, \mu \mathrm{g} / \mathrm{ml}\right)\end{array}$ \\
\hline Glucose & Glucose & 3.5 \\
Galactose & Glucose & 4.0 \\
Mannose & Glucose & 4.2 \\
Fructose & Glucose & 4.5 \\
Xylose & Glucose & 3.5 \\
Arabinose & Glucose & $\mathrm{NT}$ \\
\hline
\end{tabular}

NT: not tested.
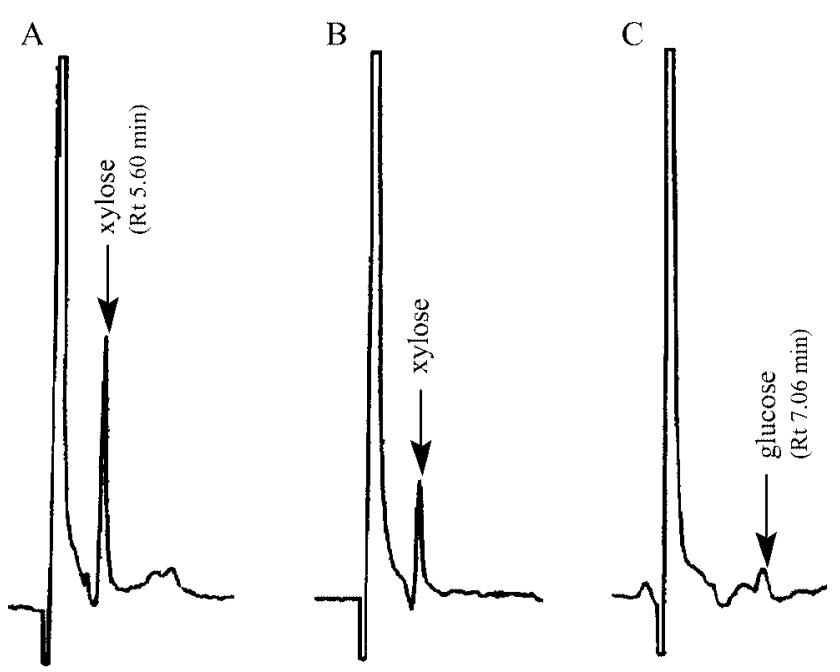

Fig. 8. Conversion of xylose to glucose in a resting-cell system. Xylose was incubated with resting-cell for 1 (A), 2 (B) and 4 (C) d. Conditions for HPLC: column, LiChrospher $100 \mathrm{NH}_{2}$, i.d. $4 \times$ $250 \mathrm{~mm}$; mobile phase, $80 \%$ acetonitrile; flow rate, $1.0 \mathrm{ml} / \mathrm{min}$, detection; RI.
Cerulenin is known as an inhibitor of fatty acid biosynthesis ${ }^{27)}$ through a polyketide pathway. By the addition of cerulenin to the actinomycete cultures that produce polyketide-antibiotics through the pathway, such as leucomycin of Streptomyces kitasatoensis, spiramycin of S. ambofaciens and tylosin of $S$. fradiae, the production of these antibiotics is inhibited without growth inhibition ${ }^{28-30)}$. To investigate whether the biosynthesis of fatty acid residues in the fattiviracin molecule occurs through this pathway or not, cerulenin was added to the culture, and the production of FV-8 in the culture filtrate was measured. As shown in Fig. 11, the addition of cerulenin at the onset, 24, 48 and $72 \mathrm{hr}$ of cultivation, inhibited the production of FV-8 by about 70 to $96 \%$ without growth inhibition. The result indicates that the fatty acid residues in the fattiviracin molecule may be biosynthesized through the polyketide pathway ${ }^{26)}$.

\section{An increased production of fattiviracins by bacitracin- resistant strain $^{31)}$}

To obtain large quantities of the compounds efficiently, improvements in productivity and purification are required. If the producing strain produced only a few fattiviracins components, the purification procedure would be simple. In this study, we demonstrate that the Streptomyces microflavus strain No. 2445 that acquired resistance for bacitracin (BC) exhibits significant quantitative and qualitative alterations in the production of fattiviracins.

Minimum inhibitory concentrations (MIC) of BC to Streptomyces microflavus strain No. 2445 (the wild strain) was determined by Waksman's agar dilution streak

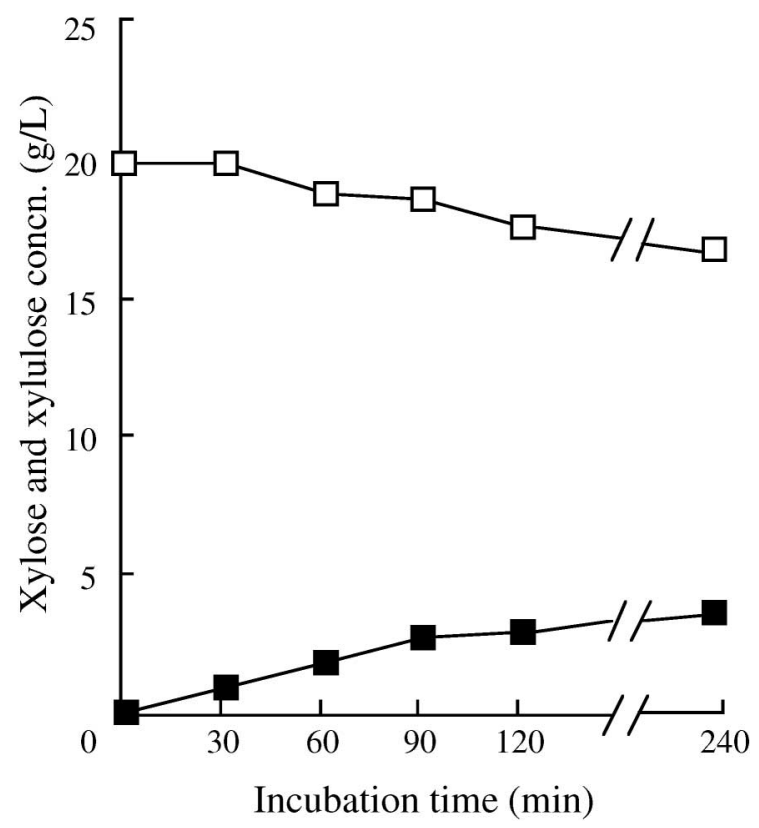

Fig. 9. Conversion of xylose to xylulose in a cell-free system. $\square$, xylose concn.; $\square$, xylulose concn. 
method $^{32)}$ using MGA agar plates consisting of glucose $1.0 \%$, asparagine $0.05 \%, \mathrm{~K}_{2} \mathrm{HPO}_{4} 0.05 \%$, yeast extract $0.05 \%$, and agar $1.5 \%$, at $\mathrm{pH} 7.0$. The MIC of the wild strain to BC was $10 \mu \mathrm{g} / \mathrm{ml}$. The spontaneous BC-resistant mutants of the wild strain were obtained as resistant colonies that grew within 10 days, after spores were spread on MGA agar plates containing BC. Spores generated on the MGA agar plate containing the highest concentration of $\mathrm{BC}$ were transferred onto MGA agar plates containing higher concentrations of $\mathrm{BC}$. This cultivation was repeatedly carried out to generate BC resistance. After 5 to 6 transfers onto MGA agar plates containing the raised con-

Table 4. ${ }_{13} \mathrm{C}$ Abundances in non-sugar moiety of fattiviracin FV-8 obtained from feeding experiments with ${ }^{13} \mathrm{C}$-labeled acetates

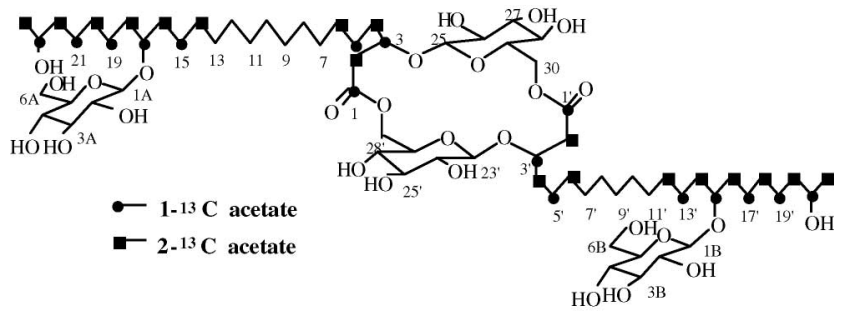

\begin{tabular}{|c|c|c|c|}
\hline \multirow{2}{*}{$\begin{array}{l}\text { Carbon } \\
\text { position }\end{array}$} & \multirow{2}{*}{$\begin{array}{c}\delta \mathrm{c} \\
\mathrm{ppm}\end{array}$} & \multicolumn{2}{|c|}{ Relative abundance ${ }^{a}$} \\
\hline & & {$\left[1-{ }^{13} \mathrm{C}\right]$ acetate } & {$\left[12-{ }^{13} \mathrm{C}\right]$ acetate } \\
\hline $1,1^{\prime}$ & 173.5 & 1.4 & 0.7 \\
\hline $2,3^{\prime}$ & 42.2 & 1.0 & 2.0 \\
\hline $3,3^{\prime}$ & 78.3 & 1.4 & 0.8 \\
\hline $4,4^{\prime}$ & 36.0 & 0.7 & 2.5 \\
\hline $5,5^{\prime}$ & 36.1 & 0.5 & 2.5 \\
\hline $6,6^{\prime}$ & 25.8 & 1.3 & $\mathrm{c}$ \\
\hline $7,7^{\prime}$ & 29.9 & $\mathrm{c}$ & 2.0 \\
\hline $8,8^{\prime}$ & 30.8 & $\mathrm{~b}$ & $\mathrm{~b}$ \\
\hline $9,9^{\prime}$ & 30.8 & $\mathrm{~b}$ & $\mathrm{~b}$ \\
\hline $10,10^{\prime}$ & 30.9 & $\mathrm{~b}$ & $\mathrm{~b}$ \\
\hline $11,12^{\prime}$ & 30.9 & $\mathrm{~b}$ & $\mathrm{~b}$ \\
\hline $13,11^{\prime}$ & 30.8 & $\mathrm{~b}$ & $\mathrm{~b}$ \\
\hline $14,12^{\prime}$ & 30.8 & $\mathrm{~b}$ & 1.5 \\
\hline $15,13^{\prime}$ & 34.9 & 0.7 & $\mathrm{c}$ \\
\hline $16,14^{\prime}$ & 30.5 & 1.7 & 2.0 \\
\hline $17,15^{\prime}$ & 40.1 & 0.8 & 0.7 \\
\hline $18,16^{\prime}$ & 80.5 & 1.3 & 0.9 \\
\hline $19,17^{\prime}$ & 80.9 & 1.6 & 2.1 \\
\hline $20,18^{\prime}$ & 30.3 & $\mathrm{c}$ & 0.9 \\
\hline $21,19^{\prime}$ & 26.8 & 1.7 & 2.0 \\
\hline $22,20^{\prime}$ & 29.9 & 0.9 & $\mathrm{c}$ \\
\hline $23,21^{\prime}$ & 24.9 & 1.8 & 1.3 \\
\hline $24,22^{\prime}$ & 40.2 & 0.6 & 0.5 \\
\hline
\end{tabular}

aPeak height ratio of ${ }^{13} \mathrm{C}$-enriched $\mathrm{FV}-8$.

${ }^{b}$ Cannot be determined due to signal overlappings or ambiguous assigment.

${ }^{\mathrm{c}}$ Not detected. centrations of $\mathrm{BC}, \mathrm{BC}-$ resistant strains (BCR) designated as $40-\mathrm{BCR}, 120-\mathrm{BCR}$ and $350-\mathrm{BCR}$ grown on the plates containing 40,120 and $350 \mu \mathrm{g} / \mathrm{ml}$ of $\mathrm{BC}$, respectively, were obtained. The spore mass color of the strain grown on MGA agar containing BC up to $20 \mu \mathrm{g} / \mathrm{ml}$ was observed as the same brownish gray as that of the wild strain, however, that of 40-BCR was gray, and those of BCR grown on MGA agar containing 60 to $350 \mu \mathrm{g} / \mathrm{ml}$ of BC turned white. The BC-resistant strains cultivated on MGA agar slants containing the same concentration of $\mathrm{BC}$ at $28{ }^{\circ} \mathrm{C}$ for 2 weeks were then stored at $5{ }^{\circ} \mathrm{C}$.

Comparison of the wild strain and 40-BCR with respect to fattiviracin production was carried out. The antiviral activity of the culture filtrate against HSV-1 was measured by the plaque reduction assay mentioned above. The residual glucose in the cultures was determined by the

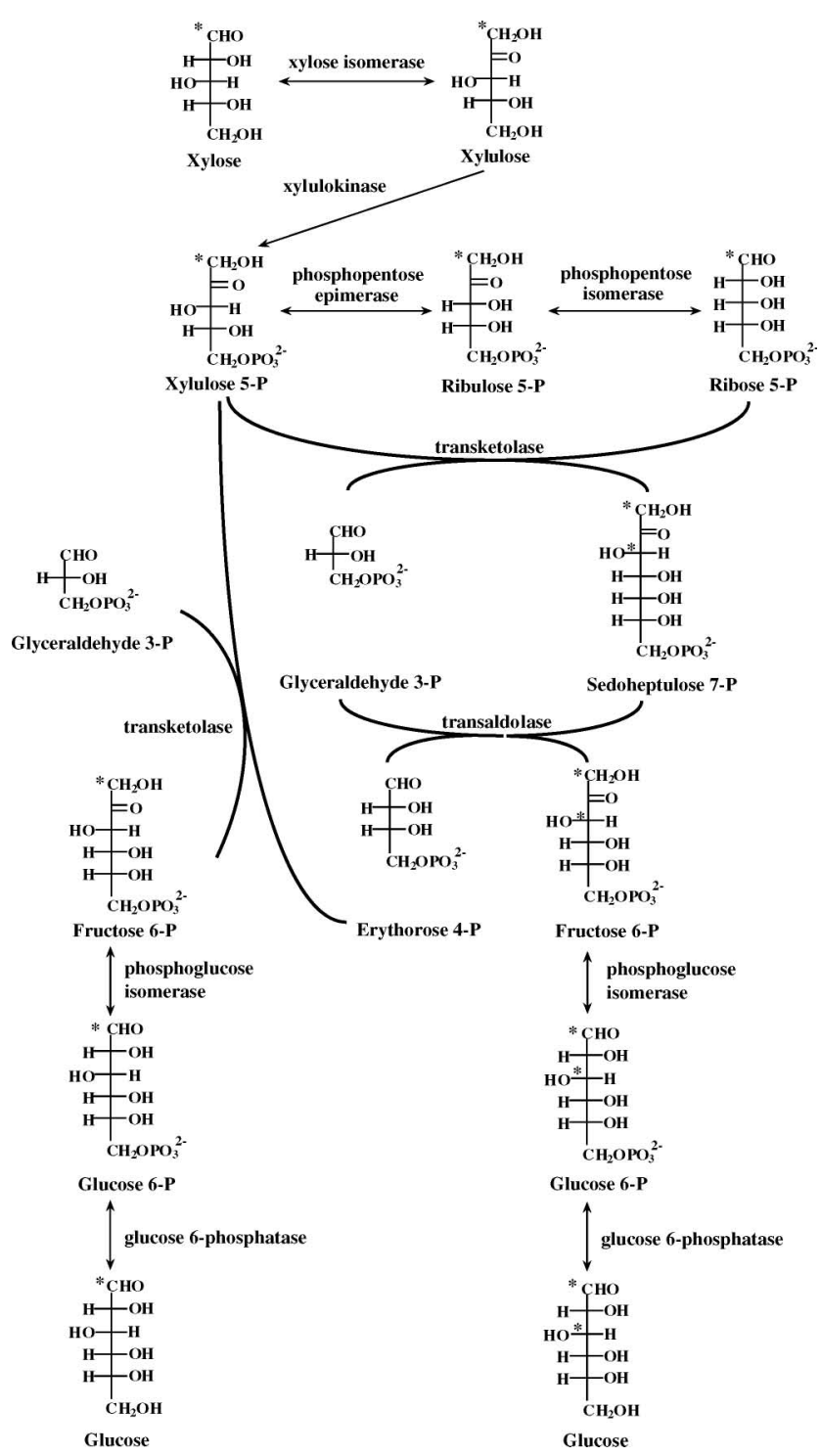

Fig. 10. Pathway for conversion of xylose to glucose.

*, ${ }^{13} \mathrm{C}$-labeled carbon. 
Somogyi-Nelson method ${ }^{33)}$. As shown in Fig. 12, the antiviral activities of the wild strain and 40-BCR were 134 and 280 unit $/ \mathrm{ml}$ after 6 days cultivation, respectively. This showed that 40-BCR produced 2.1 times more fattiviracins than the wild strain. The mycelium growth of $40-B C R$ was 1.3-fold higher than that of the wild strain after 6 days cultivation (Fig. 12). The utilization of glucose was the same for all cultures. The patterns of antiviral activity of culture filtrate and mycelium growth among 40-BCR, 120-BCR and 350-BCR were almost the same (Fig. 13). From these results, a BC-resistant concentration of $40 \mu \mathrm{g} / \mathrm{ml}$ was thought to be sufficient to raise fattiviracin production.

To investigate the fattiviracin components produced by the wild strain and 40-BCR, $500 \mathrm{ml}$ of the 6-day cultures were partially purified and fattiviracin components in the crude sample were analyzed with an analytical HPLC (column: $\mu$ Bondapak $\mathrm{C}_{18}$, Waters Associates, $4.6 \times 150 \mathrm{~mm}$, mobile phase: $90 \% \mathrm{MeOH}$, flow rate: $0.42 \mathrm{ml} / \mathrm{min}$, detection: OD at $210 \mathrm{~nm}$ ). Fig. 14 shows the different patterns of fattiviracin components. Especially, 40-BCR produced fattiviracin FV-13 exclusively, which accounted for approximately $68 \%$ of the total fattiviracin components. On the other hand, the amounts of fattiviracin FV-10 and FV-12 were lower in the 40-BCR culture. These results suggest that the fattiviracin-producing strain that acquired resistance for bacitracin has the ability to produce a higher fattiviracins and an increased FV-13 component.

The regulation of the length of fatty acid moiety in a fattiviracin molecule is important for an increased production of fattiviracins. We considered BC-resistant mutation which might regulate the membrane lipid metabolism in the fattiviracin-producing strain, would influence the production of fattiviracins. The development of fattiviracins as an antiviral drug was difficult in terms of large-scale

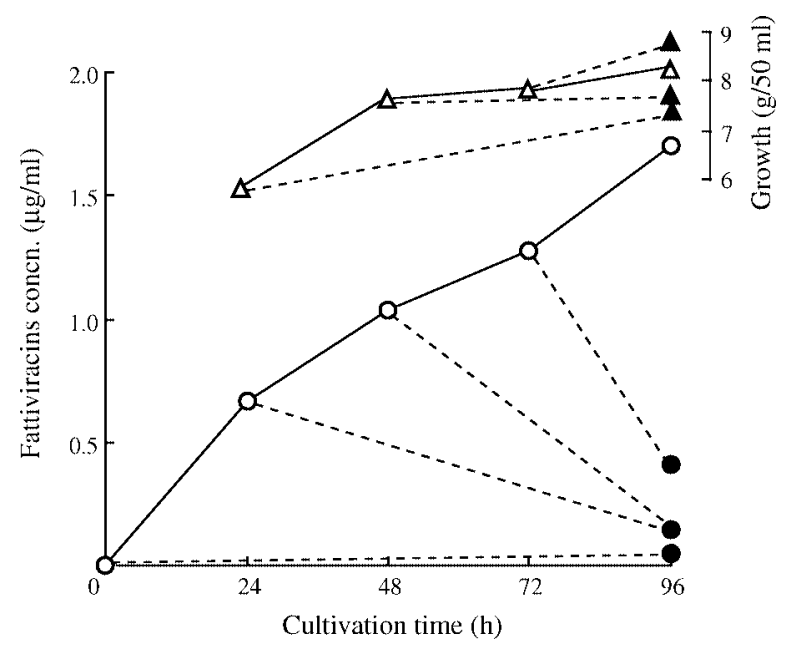

Fig. 11. Effects of cerulenin on fattiviracin production.

Cerulenin was added at $0,24,48$, and $72 \mathrm{~h}$ at a final concentration of $20 \mu \mathrm{g} / \mathrm{ml}$. FV-8 concn. $(\mu \mathrm{g} / \mathrm{ml})$ and mycelium weight were measured after $96 \mathrm{~h}$ of cultivation. $\mathrm{O}, \mathrm{FV}-8$ concn. without cerulenin; , FV-8 concn. with cerulenin; $\triangle$, cell growth without cerulenin; $\boldsymbol{\Delta}$, cell growth with cerulenin. preparation because of the low productivity and the existence of thirteen fattiviracin derivatives. However, the BCresistant strain (40-BCR) exhibits the higher antiviral activity and, in addition, more astringent productivity of fattiviracin FV-13 which has the highest molecular weight of the fattiviracin components. Large scale production of fattiviracin FV-13 is now underway with the 40-BCR. Also, the strains that acquired a resistance for higher concentrations of bacitracin (120-BCR and 350-BCR) will be studied for their strength.

The mechanism of resistance of the fattiviracin-producing strain to $\mathrm{BC}$ has not been studied. Bacitracin is one of the inhibitors of cell wall biosynthesis of bacteria. By binding to the $\mathrm{C}_{55}$-isoprenyl pyrophosphate in the presence of a divalent cation, bacitracin prevents the formation of

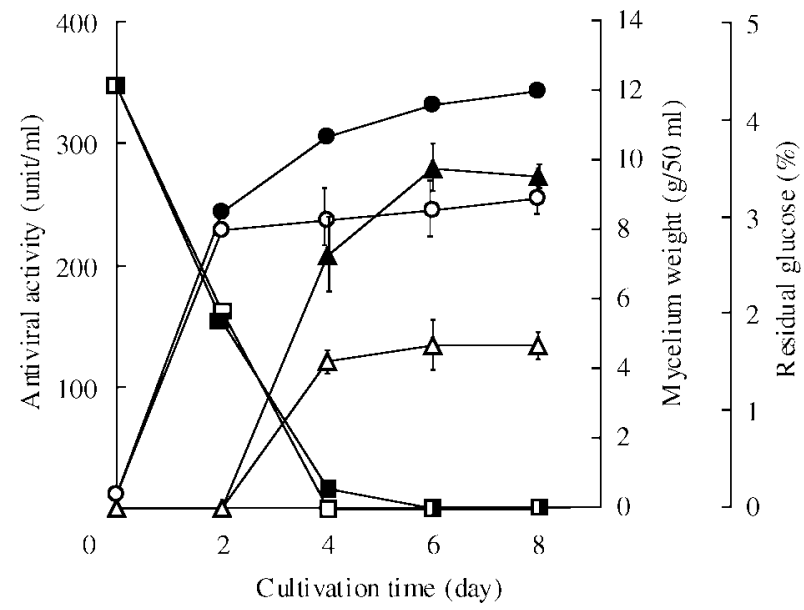

Fig. 12. Antiviral activity and cell growth of wild strain and BC-resistant strain (40-BCR) of strain No. 2445.

Wild strain and 40 -BCR were incubated at $28{ }^{\circ} \mathrm{C}$ on a rotary shaker set up at $180 \mathrm{rpm}$. Mycelium weight: $\bigcirc$, wild strain; $\bigcirc$, 40-BCR. Antiviral activity: $\triangle$, wild strain; $\boldsymbol{\Delta}, 40-B C R$. Residual glucose: $\square$, wild strain; $\square$, 40-BCR.

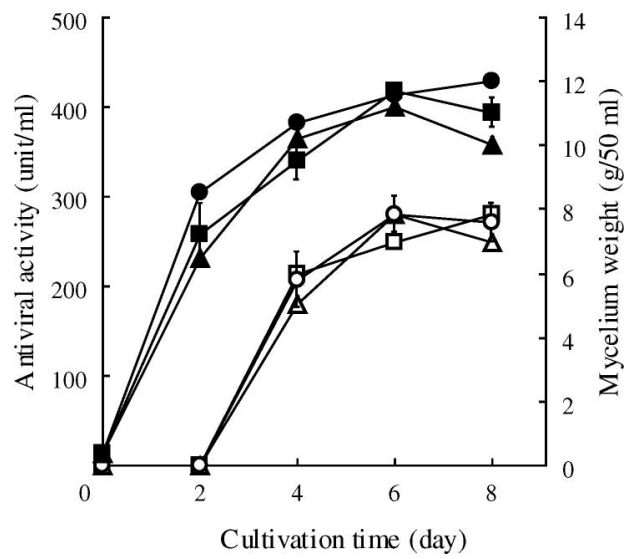

Fig. 13. Antiviral activity and cell growth of 40-BCR, 120-BCR and 350-BCR.

Antiviral activity: $\bigcirc$, 40-BCR; $\triangle, 120$-BCR; $\square, 350-B C R$. Mycelium weight: $\mathbf{O}$, 40-BCR; $\boldsymbol{\Delta}, 120-\mathrm{BCR} ; \boldsymbol{\square}, 350-\mathrm{BCR}$. 
A

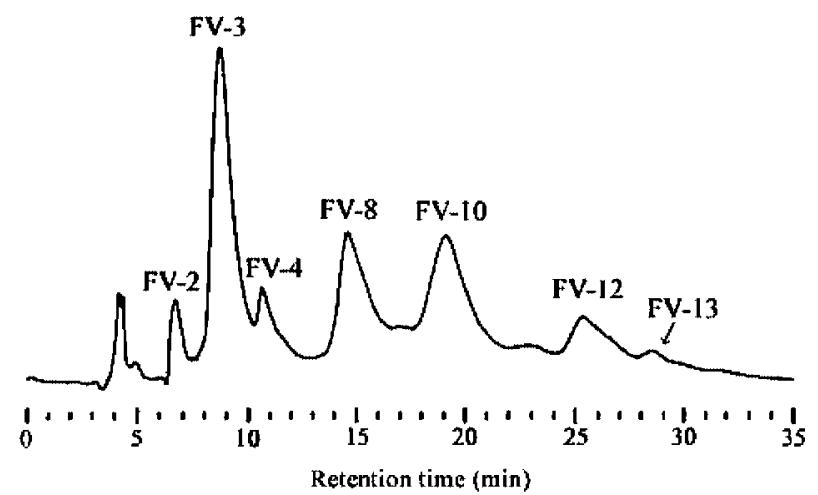

B

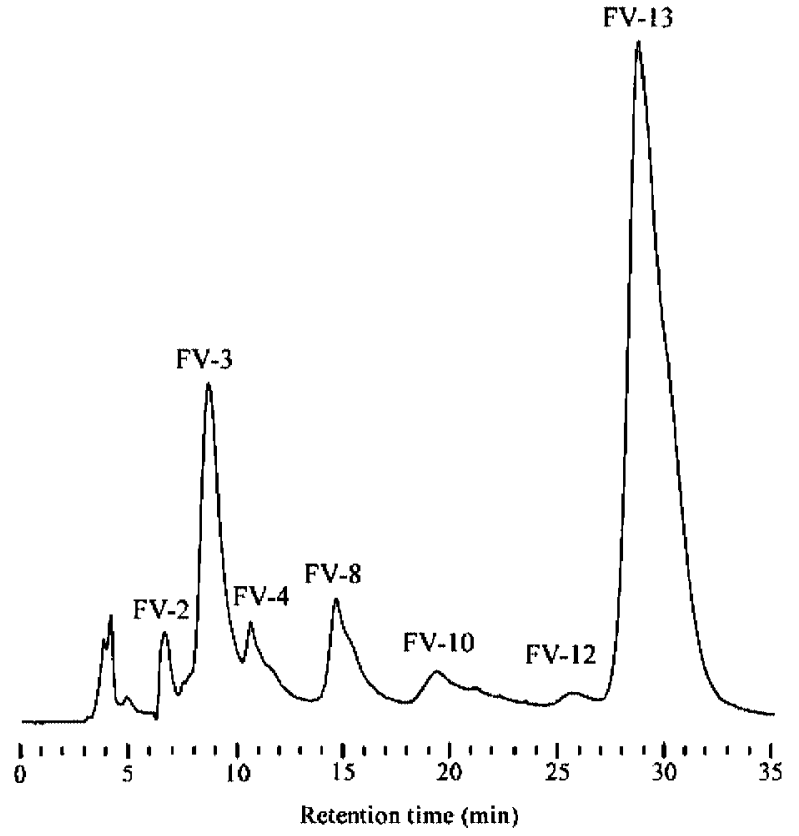

Fig. 14. HPLC profiles of the fattiviracin components in the culture filtrate from wild strain (A) and 40-BCR (B).

$\mathrm{C}_{55}$-isoprenyl phosphate. $\mathrm{C}_{55}$-isoprenyl pyrophosphate functions as a lipid carrier for the transport across the membrane of the disaccharide-pentapeptide subunits of the peptidoglycan cell wall ${ }^{34)}$ (Fig. 15). In the bacitracin-resistant strains of Escherichia coli, Streptococcus pneumoniae and Staphylococcus aureus, when membrane-associated isoprenol kinase encoded in the bacA gene is overproduced, it is able to produce sufficient quantities of $\mathrm{C}_{55}$-isoprenyl phosphate from $\mathrm{C}_{55}$-isoprenol to overcome the effects of $\mathrm{C}_{55}$-isoprenyl pyrophosphate sequestration, thereby causing bacitracin resistance ${ }^{35,36)}$. In the bacitracin-resistant strain of Streptomyces microflavus strain No. 2445 , the possibility of an increase in $\mathrm{C}_{55}$-isoprenyl phosphate or the activation of isoprenol kinase that may be related with the biosynthesis of fatty acid moieties in FV13 molecule is now under investigation.

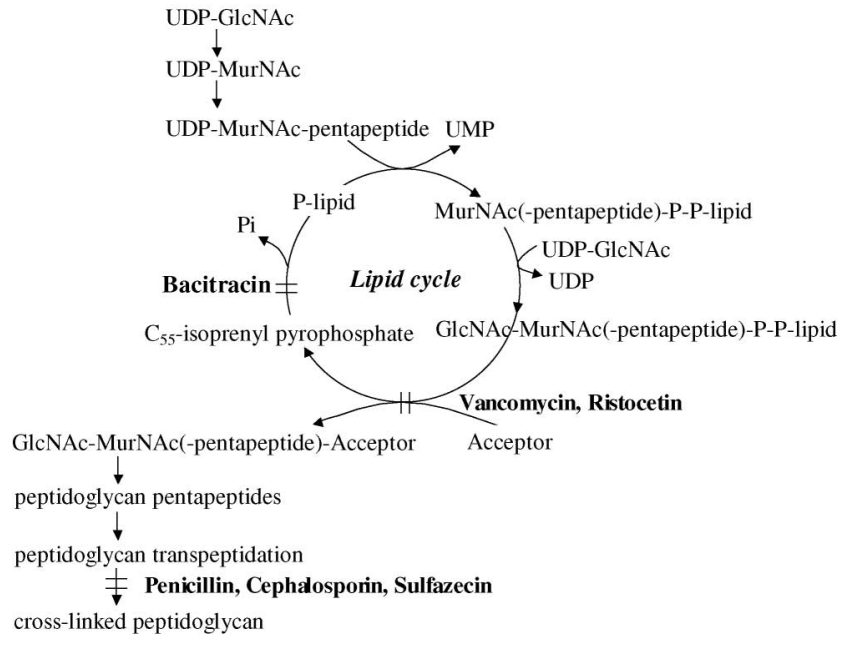

Fig. 15. Biosynthesis of cell wall peptidoglycan.

$=$, Inhibition site by antibiotics.

\section{ACKNOWLEDGMENTS}

The author would like to express his hearty thanks to Professor Arnold L. Demain at MIT (Now at R. I. S. E., Drew University, Madison, N. J.) for his warm and continuous encouragement in this work.

\section{REFERENCES}

1) Elion, G. B.; P. A. Furman, J. Fyfe, P. De Miranda, L. Beauchamp \& H. J. Schaeffer: Selectivity of action of an antiherpetic agent, 9-(2-hydroxyethoxymethyl) guanine. Proc. Natl. Acad. Sci. USA 74: 5716-5720, 1977

2) Schaeffer, H. J.; L. Beauchamp, P. De Miranda \& G. B. Elion: 9-(2-Hydroxyethoxymethyl) guanine activity against viruses of the herpes group. Nature 272: 583-585, 1978

3) Tomita, K.; Y. Hoshino \& T. Miyaki: Kibdelosporangium albatum sp. nov., producer of the antiviral antibiotics cycloviracins. Int. J. Syst. Bacteriol. 43: 297-301, 1993

4) Tsunakawa, M.; N. Komiyama, O. Tenmyo, K. Tomita, K. Kawano, C. Kotake, M. Konishi and T. Oki: New antiviral antibiotics, cycloviracins $\mathrm{B}_{1}$ and $\mathrm{B}_{2}$. I. Production, isolation, physico-chemical properties and biological activity. J. Antibiotics 45: 1467-1471, 1992

5) Tsunakawa, M.; C. Kotake, T. Yamasaki, T. Moriyama, M. Konishi \& T. Oki: New antiviral antibiotics, cycloviracins $\mathrm{B}_{1}$ and $\mathrm{B}_{2}$. II. Structure determination. J. Antibiotics 45: 1472-1480, 1992

6) McLaren, C.; M. N. Ellis \& G. A. Hunter: A colorimetric assay for the measurement of the sensitivity of herpes simplex viruses to antiviral agents. Antiviral Res. 3: 223-234, 1983

7) Schinazi, R. F.; J. Peters, C. C. Williams, D. Chance \& A. J. Nahmias: Effect of combinations of acyclovir with vidarabine or its $5^{\prime}$-monophosphate on herpes simplex viruses in cell culture and in mice. Antimicrob. Agents Chemother. 22: 499-507, 1982

8) Uyeda, M.; M. Aoki, K. Nakajima, C. Shiromoto, N. 
Tatsuguchi, K. Yokomizo, Y. Kido \& Y. Kino: A new antiherpetic agent, AH-135Y, produced by Streptomyces albovinaceus strain No. AH-135. J. Antibiotics 45: 1370-1372, 1992

9) Werner, G.; H. Hagenmaier, H. Drautz, A. Baumgartner \& H. Zähner: Metabolic products of microorganisms. 224. Bafilomycin, a new group of macrolide antibiotics. J. Antibiotics 37: 110-117, 1984

10) Uyeda, M.; K. Kondo, A. Ito, K. Yokomizo \& Y. Kido: A new antiherpetic agent produced by Streptomyces sp. strain No. 758. J. Antibiotics 48: 1234-1239, 1995

11) Kondo, S.; M. Miyamoto, H. Naganawa, T. Takeuchi \& H. Umezawa: Structures of pluramycin A and neopluramycin. J. Antibiotics 30: 1143-1145, 1977

12) Uyeda, M.; K. Yokomizo, A. Ito, K. Nakayama, H. Watanabe \& Y. Kido: A new antiherpetic agent, AH-1763 IIa, produced by Streptomyces cyaneus strain No. 1763. J. Antibiotics 50: 828-832, 1997

13) Uyeda, M.; K. Yokomizo, Y. Miyamoto \& E. E. Habib: Fattiviracin A1, a novel antiherpetic agent produced by Streptomyces microflavus strain No. 2445. I. Taxonomy, fermentation, isolation, physico-chemical properties and structure elucidation. J. Antibiotics 51: 823-828, 1998

14) Yokomizo, K.; Y. Miyamoto, K. Nagao, E. Kumagae, E. E. Habib, K. Suzuki, S. Harada \& M. Uyeda: Fattiviracin A1, a novel antiviral agent produced by Streptomyces microflavus strain No. 2445. II. Biological properties. J. Antibiotics 51: 1035-1039, 1998

15) Habib, E. E.; K. Yokomizo, K. Murata \& M. Uyeda: Structures of fattiviracin family, antiviral antibiotics. J. Antibiotics 53: 1420-1423, 2000

16) Habib, E. E.; K. Yokomizo, K. Nagao, S. Harada \& M. Uyeda: Antiviral activity of fattiviracin FV-8 against human immunodeficiency virus type 1 (HIV-1). Biosci. Biotechnol. Biochem. 65: 683-685, 2001

17) Habib, E. E.; K. Yokomizo, K. Suzuki \& M. Uyeda: Biosynthesis of fattiviracin FV-8, an antiviral agent. Biosci. Biotechnol. Biochem. 65: 861-864, 2001

18) Locci, R.: Streptomycetes and related genera. In Bergey's manual of systematic bacteriology, vol. $4 E d$., S. T. Williams, M. E. Sharpe \& J. G. Holt, pp. 2451-2504. The Williams and Wilkins Co., Baltimore, 1989

19) Shirling, E. B. \& D. Gottlieb: Methods for characterization of Streptomyces species. Int. J. Syst. Bacteriol. 16: 313-340, 1966

20) Boyd, M. R.; T. H. Bacon, D. Sutton \& M. Cole: Antiherpesvirus activity of 9-(4-hydroxy-3-hydroxymethylbut-1-yl) guanine (BRL39123) in cell culture. Antimicrob. Agents Chemother. 31: 1238-1242, 1987

21) Kimpton, J. \& M. Emerman: Detection of replication-competent and pseudotyped human immunodeficiency virus with a sensitive cell line on the basis of activation of an integrated $\beta$-galactosidase gene. J. Virology 66: 2232-2239, 1992

22) Dubreuil, M.; L. Sportza, M. D’Addario, J. Lacoste, R. Rooke, M. A. Wainberg \& J. Hiscott: Inhibition of HIV-1 transmission by interferon and $3^{\prime}$-azido- $3^{\prime}$-deoxythymidine during de novo infection of promonocytic cells. Virology 179: 388-394, 1990

23) Furman, P. A.; J. A. Fyfe, M. H. St Clair, K. Weinhold, J. L. Rideout, G. A. Freeman, S. N. Lehrman, D. P. Bolognesi, S. Broder \& H. Mitsuya: Phosphorylation of 3'-azido-3'deoxythymidine and selective interaction of the $5^{\prime}$-triphosphate with human immunodeficiency virus reverse transcriptase. Proc. Natl. Acad. Sci. USA 83: 8333-8337, 1986

24) Deeks, S. G.; M. Smith, M. Holodniy, \& J. O. Kahn: HIV-1 protease inhibitors. A review of clinicans. JAMA 277: 145-153, 1997

25) Walfridsson, M.; J. Hallborn, M. Penttila, S. Keranen \& B. H. Hahn: Xylose-metabolizing Saccharomyces cerevisiae strains overexpressing the TKL1 and TAL1 genes encoding the pentose phosphate pathway enzymes transketolase and transaldolase. Appl. Environ. Microbiol. 61: 4184-4190, 1995

26) $\mathrm{O}^{\prime}$ Hagan, D: Biosynthesis of fatty acid and polyketide metabolites. Natural Product Reports 9: 447-479, 1992

27) Omura, S: The antibiotics cerulenin, a novel tool for biochemistry as an inhibitor of fatty acid synthesis. Bacteriological Review 40: 681-697, 1976

28) Takeshima, H.; C. Kitao \& S. Omura: Inhibition of the biosynthesis of leucomycin, a macrolide antibiotic, by cerulenin. J. Biochem. 81: 1127-1132, 1977

29) Omura, S.; C. Kitao, H. Hamada \& H. Ikeda: Bioconversion and biosynthesis of 16-membered macrolide antibiotics. X. Final steps in the biosynthesis of spiramycin, using an enzyme inhibitor: cerulenin. Chem. Pharm. Bull. 27: 176-182, 1979

30) Omura, S.; C. Kato, J. Miyazawa, H. Imai \& H. Takeshima: Bioconversion and biosynthesis of 16-membered microcline antibiotic, tylosin, using an enzyme inhibitor : cerulenin. J. Antibiotics 31: 254-256, 1978

31) Uyeda, M.; T. Nagata, K. Yokomizo, T. Matsumoto, H. Toda \& K. Suzuki: Enhanced production of fattiviracins by bacitracin-resistant strains of Streptomyces microflavus strain No. 2445. J. Antibiotics 56: 876-878, 2003

32) Waksman, S. A. \& H. C. Reily: Agar-streak method for assaying antibiotic substance. Ind. Eng. Chem., Anal. Ed. 17: 556-557, 1945

33) Somogyi, M.: Notes on sugar determination. J. Biol. Chem. 195: 19-23, 1952

34) Stone, K. J. \& J. L. Strominger: Mechanism of action of bacitracin: complexation with metal ion and C55-isoprenyl pyrophosphate. Proc. Natl. Acad. Sci. USA 68: 3223-3227, 1971

35) Cain, B. D.; P. J. Norton, W. Eubanks, H. S. Nick \& C. M. Allen: Amplification of the bacA gene confers bacitracin resistance to Escherichia coli. J. Bacteriol. 175: 3784-3789, 1993

36) Chalker, A. F.; K. A. Ingraham, R. D. Lunsford, A. P. Bryant, J. Bryant, N. G. Wallis, J. P. Broskey, S. C. Pearson \& D. J. Holmes: The bacA gene, which determines bacitracin susceptibility in Streptococcus pneumoniae and Staphylococcus aureus, is also required for virulence. Microbiology 146: 1547-1553, 2000 